Vol. 8 (4): 767-776 (2018)

\title{
SOME THOUGHTS ON BOTANICAL GARDEN ESTABLISHMENT IN ARTVIN
}

\author{
Özgür Eminağaoğlu ${ }^{1 *}$, Zehra Eminağaoğlu \\ ${ }^{1 *}$ Department of Forest Engineering, Faculty of Forestry, Artvin Coruh University, Artvin- Turkey; \\ ${ }^{2}$ Department of Architecture, Art and Science Faculty, Artvin Coruh University, Artvin-Turkey; \\ *Correspondence author: Özgür Eminağaoğlu e-mail: oeminagaoglu@ artvin.edu.tr; \\ Received July, 2018; Accepted August, 2018; Published September, 2018; \\ DOI: https://doi.org/10.31407/ijees8417 \\ UOI license: http://u-o-i.org/1.01/ijees/46950646
}

\begin{abstract}
This work was carried out between 2017 and 2018 to make some evaluations on the botanical garden establishment in the province of Artvin in Turkey. In contrast to Artvin's rich flora, there are many factors that threaten this wealth, such as mining activities, dam and road construction. The botanical garden to be established in the province of Artvin will be a center where rare plants are preserved, groved medicinal and aromatic plants and visited by tourists. In this study, the possibilities of Artvin province were tried to be revealed in terms of botanical garden establishment. The following information was provided about the area where the botanical garden would be established: Legal Status, Activity Areas, Selection and Description of Site, Likely Stakeholders, Physical Elements, Infrastructure, Buildings, Miscellaneous Equipment, Organization and Staff, Financial Structure, Marketing and Public Relations Strategies, and SWOT analysis.
\end{abstract}

Key words: Artvin, Botanical Garden, design, planning, SWOT, Turkey. 